\title{
Author Correction: A therapeutic combination of two small molecule toxin inhibitors provides broad preclinical efficacy against viper snakebite
}

\author{
Laura-Oana Albulescu, Chunfang Xie, Stuart Ainsworth, Jaffer Alsolaiss, Edouard Crittenden, \\ Charlotte A. Dawson (1D, Rowan Softley, Keirah E. Bartlett, Robert A. Harrison, Jeroen Kool (1) \& \\ Nicholas R. Casewell (1)
}

Correction to: Nature Communications https:/doi.org/10.1038/s41467-020-19981-6, published online 15 December 2020.

The original version of this articles contained an error in Fig. 4. The graphs in panel B report the neutralization of SVSP venom by decreasing concentrations of the inhibitor nafamostat, from $150 \mu \mathrm{m}$ to $150 \mathrm{~nm}$, but the lowest concentration on the $X$-axis was incorrectly reported as $150 \mu \mathrm{m}$. This error has now been corrected on the PDF and HTML version of the article.

Published online: 24 June 2021

\begin{abstract}
(c) (i) Open Access This article is licensed under a Creative Commons Attribution 4.0 International License, which permits use, sharing, adaptation, distribution and reproduction in any medium or format, as long as you give appropriate credit to the original author(s) and the source, provide a link to the Creative Commons license, and indicate if changes were made. The images or other third party material in this article are included in the article's Creative Commons license, unless indicated otherwise in a credit line to the material. If material is not included in the article's Creative Commons license and your intended use is not permitted by statutory regulation or exceeds the permitted use, you will need to obtain permission directly from the copyright holder. To view a copy of this license, visit http://creativecommons.org/licenses/by/4.0/.
\end{abstract}

(C) The Author(s) 2021 